[Agr. Biol. Chem., Vol. 33, No. 3, p. 299 305, 1969]

\title{
Studies on Mucor Lipases
}

\section{Part I. Production of Lipases with a Newly Isolated Mucor sp.}

\author{
By Kozo Nagaoka, Yujiro Yamada and Yoshihisa Koaze \\ Meiji Seika Kaisha, Ltd., Research Laboratories \\ Morooka-cho, Kohoku-ku, Yokohama \\ Received May 21, 1968
}

\begin{abstract}
Mucor lipolyticus Aac-0102, a new species of Mucor, accumulated lipase in culture fluid when grown in a medium composed of soluble starch, soy bean meal, $\left(\mathrm{NH}_{4}\right)_{2} \mathrm{SO}_{4}$, and $\mathrm{K}_{2} \mathrm{HPO}_{4}$. This strain was the most lipolytic of the genus Mucor surveyed.

The culture fluid of this strain hydrolyzed various kinds of fatty acid esters, such as glycerides, Tweens or Spans and optimum activity for the hydrolysis of olive oil occurred at $\mathrm{pH}$ 8.0. This $\mathrm{pH}$ optimum was common to the lipases of the type cultures Mucor tested. The lipase of Mucor species may be different from that of Rhizopus species or other molds, since their $\mathrm{pH}$ optima are not the same.
\end{abstract}

Production of lipase with microorganisms has been reported by many investigators. Especially, lipases from Aspergillus, ${ }^{1,2)}$ Sclerotinia $^{3,4}$ Rhizopus, ${ }^{5-71}$ Candida $^{8-111}$ and some other yeasts or molds ${ }^{12,131}$ were purified and their properties have been studied in detail.

1) J. Fukumoto, M. Iwai and Y. Tsujisaka, $J$. Gen. Appl. Microbiol., 9, 353 (1963).

2) M. Iwai, Y. Tsujisaka and J. Fukumoto, ibid., 10, 13 (1964)

3) Y. Satomura, S. Oi and A. Sawada, Bull. Agr.

Chem. Soc. Japan, 22, 194 (1958).

4) Y. Satomura, S. Oi, A. Sawada and J. Fukumoto, ibid., 23, 150 (1959).

5) S. Tatsuoka, A. Miyake, S. Wada, I. Imada and C. Matsumura, $J$. Biochem., 46, 575 (1959).

6) C. Matsumura, Hakko Kyokai Shi, 20, 278 (1962).

7) J. Fukumoto, M. Iwai and Y. Tsujisaka, J. Gen. Appl. Microbiol., 10, 257 (1964).

8) K. Yamada and H. Machida, Nippon Nogeikagaku Kaishi, 36, 858 (1962).

9) N. Tomizuka, Y. Ota and K. Yamada, Agr. Biol. Chem., 30, 576 (1966).

10) K. Yamada and Y. Ota, ibid., 37, 649 (1963).

11) Y. Ota and K. Yamada, Agr. Biol. Chem., 30, 351 (1966).

12) H. Motai, H. Ichijima and F. Yoshida, Abstracts of Papers, Annual Meeting of the Agricultural Chemical Society of Japan, Tokyo, April 1, 1965, P. 11.

13) Y. Tsujisaka, M. Iwai, Y. Okamoto and J.

Fukumoto, Abstracts of Papers, Annual Meeting of the Agricultural Chemical Society of Japan, Kyoto, April 1, 1966, P. 106.
Stern $e$ al. ${ }^{141}$ reported that the culture fluid of Mucor mucedo showed some lipolytic activities, but the properties of the enzyme were not characterized. Matsumura et al. ${ }^{6}$ compared the lipase productivity of various? strains belonging to Mucoraceae and showed that the lipase productivity of the genus Mucor was much lower than that of the genus Rhizopus. The purification of lipase from Mucor species had not been reported and the properties, of lipase from Mucor were not made clear.

The authors ${ }^{15}$ found that the fungus, which was identified to be a new species of Mucor, had strong lipolytic activity. This report is concerned with the microbial characteristics of the newly isolated Mucor sp., conditions for the enzyme production and some properties of the lipolytic activity.

\section{MATERIALS AND METHODS}

Organism. Mucor sp. Aac-0102 was isolated from

14) A. M. Stern, Z. J. Ordal and H. O. Halvorson, J. Bact., 68, 24 (1954).

15) K. Nagaoka and Y. Koaze, Abstracts of Papers, Kanto Branch Meeting of the Agricultural Chemical Society of Japan, Tokyo, April 1, 1964, P. l. 
soil as the result of screening for active lipolytic microorganisms. Type cultures of the genera Mucor and Rhizopus were obtained from the Institute of Applied Microbiology, University of Tokyo.

Taxonomical studies. Morphological observations were conducted according to the descriptions of Zycha.16! Cultures grown on potato-sucrose agar $12 \%$ sucrose, $2 \%$ agar in boiled extract of $500 \mathrm{~g}$ potato with 1 liter tap water) at $28^{\circ} \mathrm{C}$ were employed for this purpose. Cultural characteristics were observed on the cultures grown at $28^{\circ} \mathrm{C}$ for 7 days. Utilization of carbon sources was determined by the cultures on Czapek's media which contain $1.09 \%$ of various carbon sources.

Medium for lipase production. The SBM-medium which consists of $4 \%$ soluble starch, $3 \%$ soy bean meal, $0.1 \%\left(\mathrm{NH}_{4}\right)_{2} \mathrm{SO}_{4}$ and $0.20^{\circ} \mathrm{K}_{2} \mathrm{HPO}_{4}$ in tap water ( $\mathrm{pH}$ 6.5) was used.

Cultural conditions. The fungus was inoculated in $30 \mathrm{ml}$ of the SBM-medium in a $100 \mathrm{ml}$ Erlemmeyer flask and cultured for $48 \sim 56 \mathrm{hr}$ at $28^{\circ} \mathrm{C}$ on a rotary shaker.

Assay of lipolytic activity. Lipase assay was performed with olive oil emulsion by the procedures of Yamada et al.17) The reaction mixture, composed of $5 \mathrm{ml}$ olive oil-polyvinyl alcohol emulsion, $4 \mathrm{ml}$ of $0.2 \mathrm{M}$ Na-phosphate buffer ( $\mathrm{pH} 8.0$ for the standard assay) and $1 \mathrm{ml}$ of enzyme solution, was incubated at $37^{\circ} \mathrm{C}$ for $50 \mathrm{~min}$. Enzyme reaction was terminated with the addition of $20 \mathrm{ml}$ acetone-ethanol mixture $(1: 1)$. Free fatty acid liberated was titrated with $0.05 \mathrm{~N} \mathrm{NaOH}$ and the titration value with boiled enzyme solution was subtracted. One unit of lipase is defined as the amount which liberates $1 \mu$ mole of fatty acid per minute at $37^{\circ} \mathrm{C}$ at $\mathrm{pH} 8.0$. Polyvinyl alcohol (PVA) was the product of Wako Pure Chemicals Co. Olive oil (Japan pharmacopoeia) was the product of Tsukishima Yakuhin Co.

\section{RESULTS}

Characteristics of Mucor sp. Aac-0102. Taxonomical characteristics of Mucor sp.

16) H. Zycha, Kriptogamenflora der Mark Brandenburg und Angrenzender Gebiete VI. a. 2, (1935).

17) K. Yamada, Y. Ota and H. Machida, Nippon Nogeikagaku Kaishi, 36, 860 (1962).

\section{TABLE I. TAXonomical CharaCteristics} oF Mucor lipolyticus Aac-0102

1. Morphological Characteristics (Fig. 1)

Aerial mycelium: White to yellowish brown

Sporangia: Yellowish brown, globose, $25 \sim 57 \mu$ in diameter, wall diffluent

Sporangiophore: Emerging singly from the mycelium, not from rhizoidiferous stolons, often monopodially or sympodially branched, 7.5 $12.5 \mu$ in width

Collumelae: Globose, hyalin, smooth, with a basal colarette, $10.5 \sim 29 \mu$ in diameter

Spores: Smooth, hyalin, short oval, $3 \sim 5 \mu \mathrm{x}$ $5 \sim 7.5 \mu$

Gemmae: Not found on sporangiophores

Zygospores: Not found on sporangiophores

2. Cultural Characteristics

Rice: Turf yellowish to yellowish brown, $10 \sim 15$ $\mathrm{mm}$ high

Malt extract agar: Growth moderate, turf white to cream, $10 \mathrm{~mm}$ high, reverse pale yellow

Czapek-glucose agar: Growth good, turf short, white to yellowish, reverse yellow

Gelatin: Growth good, enter into medium, white cottony in the medium, turf white, $3 \mathrm{~mm}$ high, sporangia poor

Potato-glucose agar: Growth good, white aerial mycelium $10 \mathrm{~mm}$ high, sporangia yellowish brown to gray

3. Physiological Characteristics

Oxygen: Aerobic

Growth pH: $3.2 \sim 9.3$

Opt. $\mathrm{pH}$ for growth: $6.0 \sim 7.0$

Growth temperature: $15^{\circ} \mathrm{C} \sim 37^{\circ} \mathrm{C}$

Opt. temperature for growth: $28^{\circ} \mathrm{C}$

Gelatin liquefaction: -

Cellulose decomposition: -

Carbon source utilization: L-Arabinose + D-Xylose + D-Glucose + D-Mannose + D-Galactose + D-Fructose + Lactose Maltose + Sucrose Melibiose Trehalose + Raffinose Inulin $\begin{array}{ll}\text { Dextrin } & + \\ \text { Starch } & +\end{array}$ 


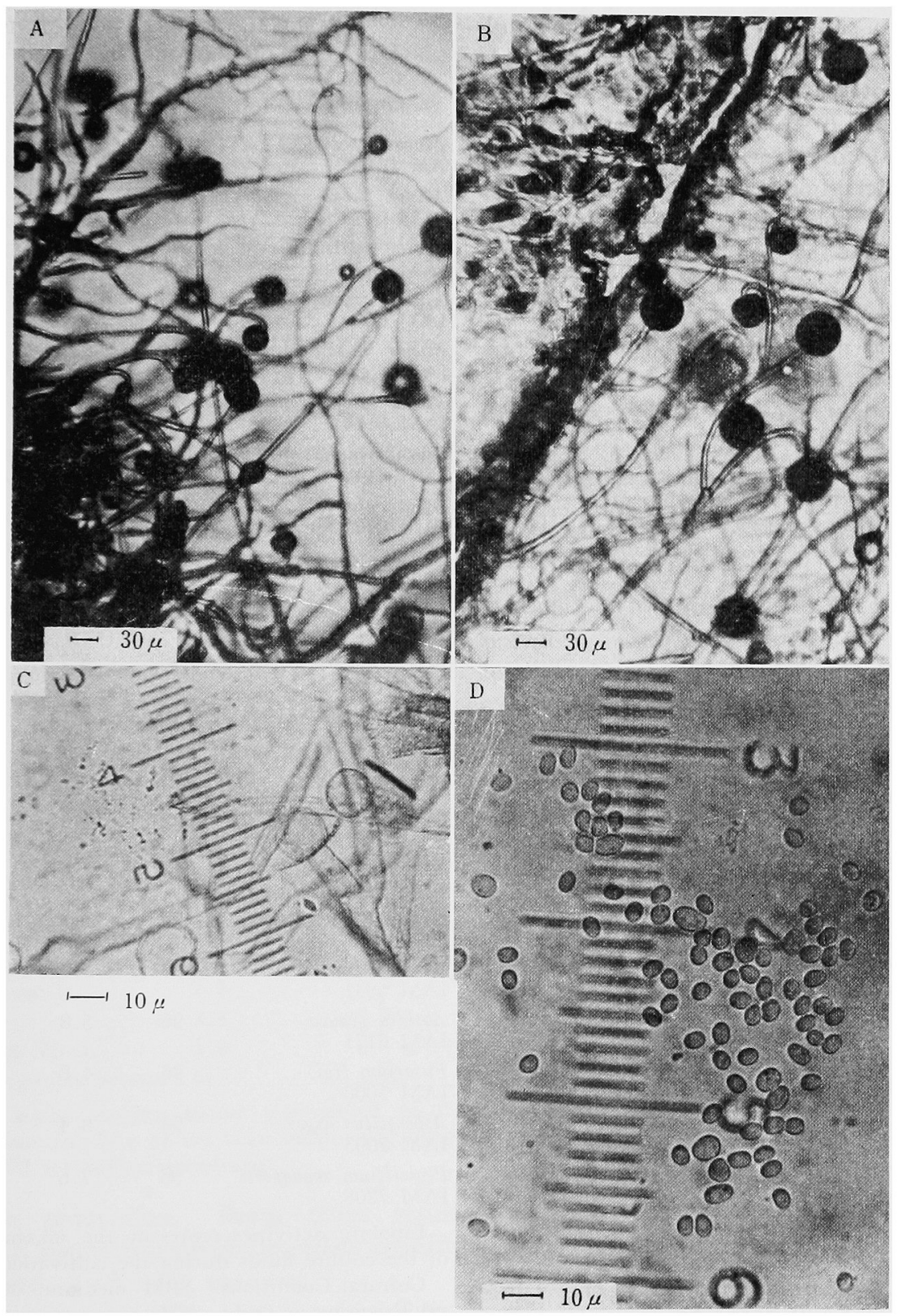

FIG. 1. A.B. Sporangia and Sporangiophores of Mucor lipolyticus Aac-0102. C. Columellae and Colarette of Mucor lipolyticus Aac-0102. D. Spores of Mucor lipolyticus Aac-0102. 
Aac-0102 are shown in Table I. The cultural characteristics of this organism resemble to the descriptions for Racemosus section or Fragilis section of Mucor. Nevertheless, the morphological characteristics are not identical with the descriptions about any one of the two sections. The isolated strain is different from Racemosus section because no gemma was found on sporangiophores, and different from Fragilis section because the spores are short oval and not more than twice as long as broad. So, the newly isolated Mucor sp. Aac-0102 is suggested to be a new species of Mucor.

This species is the most characteristic in its strong lipolytic activity and can properly be named Mucor lipolyticus Aac-0102.

\section{Comparison of lipase productivity}

As shown in Table II, Mucor lipolyticus Aac-0102 was the strongest lipase-producer of the genus Mucor tested under the conditions of this experiment. Another genus, Rhizopus, known to be lipase producers, did not show strong lipase activity in the culture fluid. These results may suggest that the favorable conditions for the lipase production with our strain are unfavorable for the others.

\section{Effect of carbon sources}

Among the carbon sources employed, soluble starch was the best for lipase production. Dextrin, glycerol, and olive oil also were suitable, but, di or monosaccharide was not suitable for lipase production (Table III).

\section{Effect of nitrogen sources}

Effect of several organic and inorganic nitrogen sources on lipase production was examined. As shown in Table IV and Table $\mathrm{V}$ soy bean meal and $\left(\mathrm{NH}_{4}\right)_{2} \mathrm{SO}_{4}$ were the most suitable combination of nitrogen sources for lipase production. The fact that the supplement of $\left(\mathrm{NH}_{4}\right)_{2} \mathrm{SO}_{4}$ gave by far the better result than any other ammonium salts suggests that $\mathrm{SO}_{4}^{-2}$ has some favorable effect on lipase
Table II. Lipase Productivity OF VARIOUS MOLDS

\begin{tabular}{|c|c|c|c|}
\hline Organisms & $\begin{array}{l}\text { Incubation } \\
\text { time (hr) }\end{array}$ & $\underset{\text { (final) }}{\mathrm{pH}}$ & $\begin{array}{c}\text { Lipolytic } \\
\text { activity }(\mathrm{u} / \mathrm{ml})\end{array}$ \\
\hline $\begin{array}{l}\text { Mucor lipolyticus } \\
\text { Aac-0102 }\end{array}$ & 55 & 7.6 & 90.2 \\
\hline $\begin{array}{l}\text { Mucor flavus } \\
\text { IAM } 6143\end{array}$ & 55 & 7.5 & 34.1 \\
\hline $\begin{array}{l}\text { Mucor petrisularis } \\
\text { IAM } 6115\end{array}$ & 70 & 7.7 & 3.80 \\
\hline $\begin{array}{l}\text { Mucor circinelloides } \\
\text { IAM } 6080\end{array}$ & 53 & 7.7 & 3.04 \\
\hline $\begin{array}{l}\text { Mucor javanicus } \\
\text { IAM } 6089\end{array}$ & 70 & 5.7 & 3.04 \\
\hline $\begin{array}{l}\text { Mucor lamprosporus } \\
\text { IAM } 6114\end{array}$ & 70 & 7.7 & 2.28 \\
\hline $\begin{array}{l}\text { Mucor fragilis } \\
\text { IAM } 6140\end{array}$ & 55 & 7.8 & 1.92 \\
\hline $\begin{array}{l}\text { Mucor praini } \\
\text { IAM } 6120\end{array}$ & 53 & 7.5 & 1.52 \\
\hline $\begin{array}{l}\text { Mucor jansseni } \\
\text { IAM } 6099\end{array}$ & 56 & 4.8 & 1.52 \\
\hline $\begin{array}{l}\text { Mucor mandschuricus } \\
\text { IAM } 6118\end{array}$ & 56 & 7.4 & 1.52 \\
\hline $\begin{array}{l}\text { Mucor dimorphosporus } \\
\text { IAM } 6083\end{array}$ & 56 & 5.7 & 0.76 \\
\hline $\begin{array}{l}\text { Mucor hiemalis } \\
\text { IAM } 6088\end{array}$ & 56 & 5.7 & 0.90 \\
\hline $\begin{array}{l}\text { Mucor javanicus } \\
\text { IAM } 6101\end{array}$ & 55 & 7.6 & 0.48 \\
\hline $\begin{array}{l}\text { Mucor lamannianus } \\
\text { IAM } 6128\end{array}$ & 56 & 5.4 & 0.40 \\
\hline $\begin{array}{l}\text { Rhizopus oryzae } \\
\text { IAM } 6001\end{array}$ & 72 & 5.8 & 2.55 \\
\hline $\begin{array}{l}\text { Rhizopus formosaensis } \\
\text { IAM } 6243\end{array}$ & 96 & 7.3 & 1.97 \\
\hline $\begin{array}{l}\text { Rhizopus niveus } \\
\text { IAM } 6031\end{array}$ & 96 & 5.8 & 0.40 \\
\hline $\begin{array}{l}\text { Absidia glauca } \\
\text { IAM } 6171\end{array}$ & 96 & 5.8 & 0.80 \\
\hline $\begin{array}{l}\text { Fusarium lini } \\
\text { IAM } 5008\end{array}$ & 96 & 4.8 & 0.60 \\
\hline $\begin{array}{l}\text { Aspergillus niger } \\
\text { IAM } 2093\end{array}$ & 96 & 8.4 & 0.40 \\
\hline $\begin{array}{l}\text { Penicillium roqueforti } \\
\text { IAM } 7268\end{array}$ & 96 & 7.6 & 6.00 \\
\hline
\end{tabular}

Lipolytic activities represent the maximum values of the culture fluids during the cultivation.

Cultural Conditions: SBM medium, $30 \mathrm{ml}$ in 100 $\mathrm{ml}$ Erlemmeyer flasks, $28^{\circ} \mathrm{C}$ on a rotary shaker.

production. So, the effect of some sulfur containing materials on lipase production was examined. As shown in Table VI, addition of sulfur compounds resulted in some increase 
TABLE III. EFFECT OF CaRBon Sources oN LIPASE PRoduction WITH Mucor lipolyticus Aac-0102

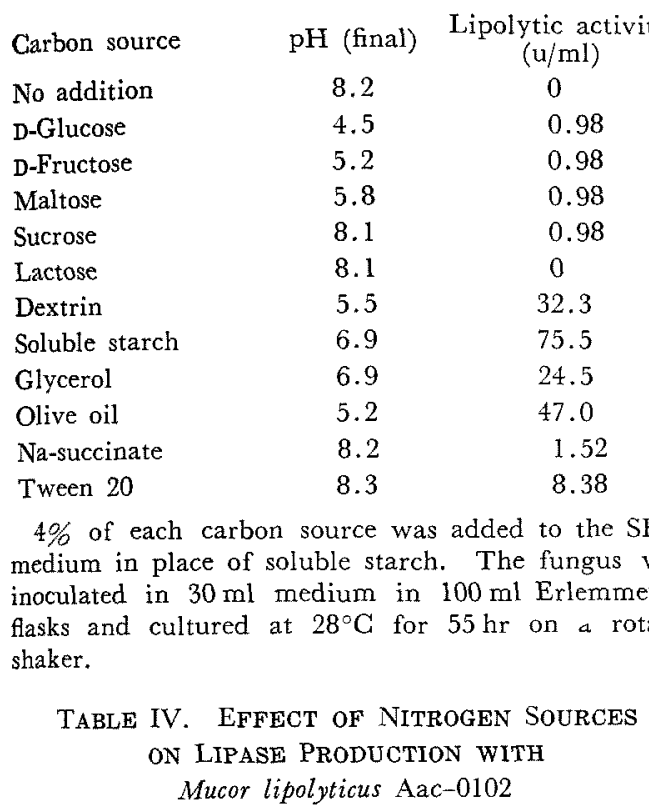

$\begin{array}{lcc}\text { Nitrogen source } & \mathrm{pH} \text { (final) } & \begin{array}{c}\text { Lipolytic activity } \\ (\mathrm{u} / \mathrm{ml})\end{array} \\ \text { No addition } & 2.6 & 1.96 \\ \text { Casamino acid } & 8.0 & 0.98 \\ \text { Yeast extract } & 8.2 & 2.29 \\ \text { Polypeptone } & 8.5 & 0 \\ \text { Tryptone } & 7.9 & 0 \\ \text { NZ-case } & 8.7 & 1.52 \\ \text { Soy bean meal } & 7.5 & 70.6 \\ \text { Kinako } & 4.4 & 3.90 \\ \text { Corn steep liquor } & 7.9 & 0 \\ \text { Soluble vegitable protein } & 6.7 & 4.90\end{array}$

$3 \%$ of each nitrogen source was added to the SBM-medium in place of soy bean meal. See legend of Table III for cultural conditions.

of lipase production. From these results $\left(\mathrm{NH}_{4}\right)_{2} \mathrm{SO}_{4}$ seems to contribute rather as sulfur source than as nitrogen source.

\section{Time course of lipase production}

Time course of lipase production was followed with enzyme assay, determination of total sugar and $\mathrm{pH}$ of the culture filtrate (Fig. 2). The patterns of time course changed
TABLE V. EFFECT OF INORGanic SOURCES ON LIPASE PRODUCTION WITH Mucor lipolyticus Aac-0102

\begin{tabular}{lcc}
\multicolumn{1}{c}{ Additions } & $\mathrm{pH}$ (final) & $\begin{array}{c}\text { Lipolytic activity } \\
(\mathrm{u} / \mathrm{ml} \text { ) }\end{array}$ \\
No addition & 7.9 & 7.84 \\
Ammonium acetate & 8.0 & 3.92 \\
Ammonium carbonate & 8.0 & 3.92 \\
Ammonium chloride & 7.9 & 3.92 \\
$\begin{array}{l}\text { Ammonium citrate } \\
\text { (dibasic) }\end{array}$ & 8.0 & 2.94 \\
Ammonium nitrate & 8.1 & 2.94 \\
Ammonium phosphate & 8.1 & 2.94 \\
$\quad$ (dibasic) & & \\
Ammonium sulfate & 7.4 & 62.7 \\
Urea & 7.6 & 1.96 \\
Sodium nitrate & 8.0 & 0
\end{tabular}

Addition was made to the SBM-medium in place of ammonium sulfate. Concentration of each nitrogen source corresponds to $0.1 \%$ ammonium sulfate in regard to nitrogen. See legend of Table III for cultural conditions.

\section{TABLE VI. EFFECT OF SUlFur Compound AND AMMONIUM SALTS ON LIPASE PRODUCTION WITH Mucor lipolyticus Aac-0102}

Additions

Concentration $\mathrm{pH}$ Lipolytic

$(\%) \quad$ (final) activity $(\mathrm{u} / \mathrm{ml})$

No addition

$7.4 \quad 20.5$

Cysteine $\cdot \mathrm{HCl}$

$\begin{array}{lll}0.15 & 7.3 & 45.7\end{array}$

$\left(\mathrm{NH}_{4}\right)_{2} \mathrm{SO}_{4}$

$0.10 \quad 7.0 \quad 46.4$

$\mathrm{Na}_{2} \mathrm{SO}_{4} \cdot 10 \mathrm{H}_{2} \mathrm{O}$

0.28

7.4

32.7

$\mathrm{NH}_{4} \mathrm{Cl}$

0.09

7.8

1.52

$\mathrm{Na}_{2} \mathrm{SO}_{4} \cdot 10 \mathrm{H}_{2} \mathrm{O}$

0.28

0.09

6.6

50.2

$+\mathrm{NH}_{4} \mathrm{Cl}$

Addition was made to the SBM-medium in place of $\left(\mathrm{NH}_{4}\right)_{2} \mathrm{SO}_{4}$. Concentration of each sulfur compound corresponds to $0.1 \%\left(\mathrm{NH}_{4}\right)_{2} \mathrm{SO}_{4}$ in regard to sulfur. Cultural conditions were similar to those in Table III.

more or less when the composition of the medium was changed, but excretion of the enzyme generally began after fungal growth reached its maximum and concurrently about half of the carbon source was consumed. In the early stage of the cultivation, $\mathrm{pH}$ of the broth fell down to about 5.0, then, turned to rise. As the $\mathrm{pH}$ of the broth rose, the lipolytic activity of the supernatant fluid increased. When the $\mathrm{pH}$ of the broth reached 


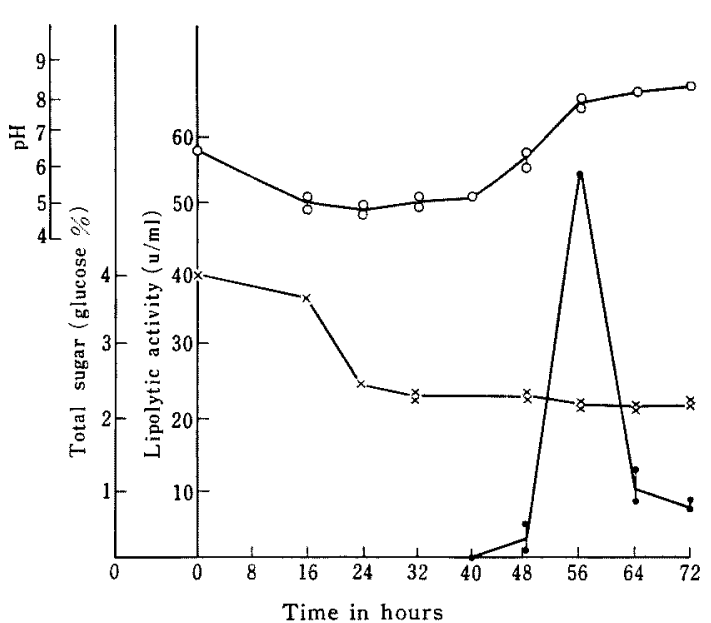

FIG. 2. Time Course of Cultivation with Mucor lipolyticus Aac-0102.

O-O pH $\times-\times$ Total sugar - Lipase.

Cultural conditions: SBM medium $30 \mathrm{ml}$ in $100 \mathrm{ml}$ Erlemmeyer flasks, $28^{\circ} \mathrm{C}$ on a rotary shaker.

to 8.0 , lipolytic activity began to decrease. When olive oil was used as the carbon source, the $\mathrm{pH}$ of the broth remained around 5.0, but lipolytic activity appeared in culture fluid after $55 \mathrm{hr}$ incubation in spite of its low $\mathrm{pH}$ (Table III).

\section{Some properties of crude enzyme preparation}

As shown in Table VII, optimum $\mathrm{pH}$ for olive oil hydrolysis in the culture fluid of Mucor and Rhizopus were 8.0 and 7.0, respectively. Most of the lipolytic activity in the culture fluid was precipitated at $50 \%$ saturation with $\left(\mathrm{NH}_{4}\right)_{2} \mathrm{SO}_{4}$. The precipitate was desalted dialyzing over night at $5^{\circ} \mathrm{C}$ against distilled water and freeze dried. This powder was used as crude enzyme preparation. This preparation had hydrolytic activities toward many kinds of fatty acid esters. The results are shown in Table VIII. Optimum $\mathrm{pH}$ for the hydrolytic activity of the crude enzyme was 8.0 for olive oil and 7.0 for Tween 20 .
TABLE VII. OPTIMUM pH FOR LIPOLYTIC ACTIVITY IN CULTURE FLUIDS OF VARIOUS MOLDS

\begin{tabular}{|c|c|c|c|}
\hline & $\begin{array}{c}\text { Mucor } \\
\text { lipolyticus } \\
\text { Aac-0102 }\end{array}$ & 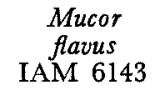 & $\begin{array}{c}\text { Mucor } \\
\text { circinelloides } \\
\text { IAM } 6080\end{array}$ \\
\hline $\mathrm{pH}$ & \multicolumn{3}{|c|}{ Relative activity (maximum $=100$ ) } \\
\hline 3.0 & 10.0 & 11.3 & 2.7 \\
\hline 4.0 & 24.0 & 41.4 & 4.3 \\
\hline 5.0 & 40.0 & 54.0 & 13.0 \\
\hline 6.0 & 58.0 & 73.0 & 34.0 \\
\hline 7.0 & 68.0 & 86.5 & 45.0 \\
\hline 8.0 & 100 & 100 & 100 \\
\hline 9.0 & 57.5 & 81.1 & 17.0 \\
\hline & $\begin{array}{c}\text { Rhizopus } \\
\text { formosaensis } \\
\text { IAM } 6243\end{array}$ & $\begin{array}{l}\text { Rhizopus } \\
\text { chinensis } \\
\text { IAM } 6003\end{array}$ & $\begin{array}{c}\text { Rhizopus } \\
\text { oryzae } \\
\text { IAM 6001 }\end{array}$ \\
\hline $\mathrm{PH}$ & \multicolumn{3}{|c|}{ Relative activity $(\operatorname{maximum}=100)$} \\
\hline 3.0 & 37.8 & 38.4 & 23.0 \\
\hline 4.0 & 68.0 & 73.0 & 58.2 \\
\hline 5.0 & 79.5 & 69.0 & 62.3 \\
\hline 6.0 & 92.6 & 84.6 & 68.9 \\
\hline 7.0 & 100 & 100 & 100 \\
\hline 8.0 & 35.8 & 61.5 & 51.4 \\
\hline
\end{tabular}

TABLE VIII. HydRolysis OF SEVERAL FatTy ACID ESTERS WITH Mucor LIPASE AND WITH PANCREATIN

Substrate

Relative activity (maximum $=100$ )

\section{Triacetin}

Tributyrin

Triolein

$\alpha$-Monoolein

$\begin{array}{cc}\text { Mucor lipase } & \text { Pancreatin } \\ 5.89 & 57.6 \\ 100 & 100 \\ 51.6 & 13.9 \\ 34.3 & 23.0 \\ 80.2 & 8.25 \\ 41.6 & 1.81 \\ 53.5 & - \\ 44.4 & 1.61 \\ 55.4 & 17.5 \\ 40.1 & 4.82 \\ 71.6 & 5.84\end{array}$

Tween 20

Tween 60

Tween 80

Span 20

Span 80

Polyoxyethyleneglycol monolaurate

Methyl-n-butyrate

3.98

59.6

The reaction mixture, composed of $1 \mathrm{~g}$ of substrate, $8 \mathrm{ml}$ of $0.1 \mathrm{M}$ phosphate buffer $(\mathrm{pH} \mathrm{7.0)}$ and $2.5 \mathrm{mg}$ of crude Mucor lipase or $20 \mathrm{mg}$ of Pancreatin (Japan pharmacopoeia) in $1 \mathrm{ml}$ distilled water, was shaken in L-shaped tube for $18 \mathrm{hr}$ at $37^{\circ} \mathrm{C}$.

Termination of the reaction and titration of the mixture were carried out in the same way as lipase assay. 


\section{DISCUSSION}

The lipase of the genus Mucor has not been used industrially as a source of lipase, because lipase productivity was much lower than that of other molds like Rhizopus. ${ }^{6}$ However, as shown in Table II, the newly isolated strain, Mucor lipolyticus Aac-0102, was found to accumulate more lipase in culture fluid than any other strains tested. The productivity of lipase of this organism depends on the cultural conditions. In the case of Rhizopus good results are obtained with addition of $\mathrm{CaCO}_{3}$ to the medium, ${ }^{6)}$ but the results of our preliminaly experiments to determine optimum composition of culture medium showed that the addition of $\mathrm{CaCO}_{3}$ to the medium was not favorable for lipase production by Mucor. The composition of the SBM medium seems to be the most adequate one for lipase production by Mucor lipolyticus Aac-0102. As shown in Fig. $2 \mathrm{pH}$ of the culture broth of this strain was kept above 4.0 without any control of $\mathrm{pH}$, and during $48 \sim 64 \mathrm{hr}$ of incubation $\mathrm{pH}$ of the culture fluid rose to $6.0 \sim 8.0$. This $\mathrm{pH}$ range might be the favourable condition for enzyme excretion. When glucose was employed as carbon source, $\mathrm{pH}$ of the culture fluid fell down and it took long time to come to the favorable condition for enzyme excretion. This may be one of the reasons for glucose inhibition of lipase production. On the other hand, when olive oil was used as a carbon source lipase was excreted in the earlier stage of cultivation in spite of the low $\mathrm{pH}$ of the culture. This fact suggests the possibility that olive oil or some lipophylic substances derived from it might play a role in the formation or excretion of lipase under unfavorable condition.

In many cases of lipase production by microorganisms $\left(\mathrm{NH}_{4}\right)_{2} \mathrm{SO}_{4}$ is supplemented to media, ${ }^{6,18}$ but the reason for this is not

18) K. Yamada, H. Machida, T. Higashi, A. Koide and K. Ueda, Nippon Nogeikagaku Kaishi, 37, 645 (1963). explained enough. As shown in Table VI, the stimulative effect of $\left(\mathrm{NH}_{4}\right)_{2} \mathrm{SO}_{4}$ on lipase production by Mucor lipolyticus Aac-0102 was primarily due to $\mathrm{SO}_{4}^{-2} \quad \mathrm{NH}_{4}^{+}$and $\mathrm{SO}_{4}^{-2}$ seemed to have some synergistic effect on lipase production by this strain. On these bases $\left(\mathrm{NH}_{4}\right)_{2} \mathrm{SO}_{4}$ seemed to be the most appropriate compound as the component of the medium and the optimum concentration was $0.1 \%$.

Optimum $\mathrm{pH}$ for the hydrolysis of olive oil by culture filtrate or crude enzyme preparation was 8.0 and it was common to the type cultures of Mucor tested. The optimum $\mathrm{pH}$ of Mucor lipase was apparently different from that of Rhizopus, whose optimum $\mathrm{pH}$ was 7.0

Crude enzyme preparation of this enzyme had hydrolytic activity toward many kinds of fatty acid esters including water soluble ones. Hydrolytic activity of the enzyme preparation toward water soluble esters such as Tweens was relatively higher than that of pancreatin. On the other hand, esterase activity was much weaker than that of pancreatin.

In the course of purification lipolytic activity of the crude enzyme was separated into several fractions, suggesting the presence of various types of lipases in crude enzyme powder. The results of the purification of the enzyme will be reported subsequently.

Acknowledgement. The authors wish to express their sincere gratitude to Prof. K. Arima and Assist. Prof. G. Tamura of the University of Tokyo for the guidance and encouragement to this work.

They also wish to express their thanks to Prof. $H$. Iizuka, Institute of Applied Microbiology, The University of Tokyo, for his valuable advices in the identification of the fungus, Thanks are due to Dr. $T$. Hara of this laboratory for the direction through this work and to Miss K. Katsumata for her technical assistance. 